\title{
EXHALED NITRIC OXIDE LEVELS AFTER SPECIFIC INAHALATORY CHALLENGE TEST IN SUBJECTS WITH DIAGNOSED OCCUPATIONAL ASTHMA
}

\author{
DOMINIKA ŚWIERCZYŃSKA-MACHURA ${ }^{1}$, ANNA KRAKOWIAK², MARTA WISZNIEWSKA ${ }^{2}$, \\ WOJCIECH DUDEK ${ }^{1}$, JOLANTA WALUSIAK ${ }^{2}$, and CEZARY PALCZYŃSKI ${ }^{1,2}$ \\ ${ }^{1}$ Nofer Institute of Occupational Medicine, Łódź, Poland \\ Centre of Occupational and Environmental Allergy \\ ${ }^{2}$ Nofer Institute of Occupational Medicine, Lódź, Poland \\ Department of Occupational Diseases
}

\begin{abstract}
Objectives: Measuring exhaled nitric oxide (eNO) is a useful method for the assessment of bronchial inflammation in asthmatic subjects. The aim of the study was to evaluate the changes in eNO level in the subjects with suspected occupational asthma (OA) after a specific inhalation test (SIT) with occupational agents. Materials and Methods: Forty two patients, including 17 farmers, 15 bakers and 10 health care workers had a physical examination, skin prick tests with common and occupational allergens, total serum IgE level, specific anti-allergen IgE determinations, spirometry and SIT. Also, morphological changes in induced sputum (ISP) and nasal lavage fluid (NLF) were analysed and eNO measurements were performed. Results: SIT revealed a significant increase in the proportion of eosinophils in NLF and in ISP in the cases with diagnosed OA. Moreover, these cases showed significantly increased eNO levels only $24 \mathrm{~h}$ after SIT, compared to the measurements before SIT. We also found a significant correlation between eNO level at $24 \mathrm{~h}$ after SIT and the percentage of eosinophils in NLF before, and 4 and $24 \mathrm{~h}$ after SIT, as well as in ISP before and $24 \mathrm{~h}$ after SIT in all subjects with diagnosed OA. Conclusion: The findings may confirm the usefulness of exhaled nitric oxide measurements for diagnosing OA.
\end{abstract}

Key words:

Nitric oxides, Occupational asthma, Diagnostics

\section{INTRODUCTION}

Nitric oxide (NO) is an endogenous, soluble gas. Its highly reactive molecules are involved in many biological and pathophysiological organic processes [1]. It is generated from arginine through the activity of nitric oxide synthase, an enzyme that has three isoforms (NOS-1, NOS-2, NOS-3). One of them, called the inducible nitric oxide synthase (NOS-2 or iNOS), is more active than the other two and its synthesis continues to increase under conditions of an inflammation [2,3]. The iNOS expression correlates with the exhaled nitric oxide (eNO) level [4].
Allergic airway inflammation plays a crucial role in the pathogenesis of asthma. Over the last several years, attempts have been made to develop accurate and non-invasive diagnostic methods for this particular inflammation. Lately, great hopes have been associated with the use of measurements of exhaled nitric oxide for estimating bronchial inflammation in asthmatic subjects [5-7]. Furthermore, positive correlations between eNO and blood eosinophilia and the number of sputum eosinophils in atopic children and asthmatic adults have been observed [8,9]. The aim of the present study was to evaluate the changes in eNO in subjects with suspected occupational asthma (OA) after a specific inhalation test (SIT) with occupational

Received: November 5, 2007. Accepted: August 1, 2008.

Address reprint requests to D. Świerczynska-Machura, Centre of Occupational and Environmental Allergy, Nofer Institute of Occupational Medicine, Św. Teresy 8, 91-348 Łódź, Poland (e-mail: mika@imp.lodz.pl). 
agents. In addition, the authors searched for a correlation between the percentage of eosinophils in induced sputum (ISP) and nasal lavage fluid (NLF) of the subjects with diagnosed OA.

\section{MATERIALS AND METHODS}

\section{Materials}

The subjects comprised 42 patients ( 18 women and 24 men) with suspected OA who were referred to the Department of Occupational Diseases for a consultation. The study group included bakers, farmers and health care workers (HCWs). The study was approved by the local Biomedical Ethics Committee and all the subjects presented their written informed consent prior to the study.

\section{Methods}

Questionnaire

Each subject had a medical history collected to gain information on the history of atopy, occupational exposure, respiratory symptoms, the presence of animals at home and the smoking status.

\section{Skin prick tests}

Skin prick tests (SPTs) were performed on the volar part of the forearm. Common allergens included tree and grass pollens, Dermatophagoides pteronyssinus, Dermatophagoides farinae, moulds, feathers (Allergopharma, Germany) while the occupational allergens were represented by a standarized battery of different kinds of flours, $\alpha$-amylase, several kinds of hays, animal furs, threshings, cereals, storage mites (Allergopharma, Germany) in the tests on bakers and farmers and latex in testing HCWs (Stallergen, France). The SPTs were performed according to standardized techniques [10].

Total and specific IgE

Total IgE was evaluated with the Uni-CAP system (Pharmacia, Sweden). Specific IgE antibodies to occupational allergens were measured using the Uni-CAP system (Pharmacia, Sweden): wheat, barley and rye flour, $\alpha$-amylase and latex; or with Allergopharma system (Germany): wheat, oat, maize, sesame flour, grass, and corn, and also sheep, pig, cow, horse epidermis and furs, grass and cereal pollens. Specific IgE values $>0.35 \mathrm{kU} / \mathrm{l}$ were regarded as positive.

Inhalation challenge tests

SIT was performed in a worksite simulation setting (room space $6 \mathrm{~m}^{2}$ ) with the patient's own samples. Bakers had SIT with wheat, rye, corn, barley or oatmeal flour. The patient was sifting approximately $100 \mathrm{~g}$ of each kind of flour and $10 \mathrm{~g}$ of bakers' additives for $30 \mathrm{~min}$. SIT performed on farmers included the following materials: grain dust, animal epidermis, furs, feathers, several kinds of hays and cereals.

HCWs had SIT with latex gloves: they were powdering them with talc for $30 \mathrm{~min}$.

Pulmonary function and histamine challenge testing

Resting spirometry (Vicatest 2A, Mijnhardt, The Netherlands) was performed in all subjects. Bronchial response was measured by serial monitoring of forced expiratory volume in $1 \mathrm{~s}\left(\mathrm{FEV}_{1}\right)$ and peak expiratory flow rate (PEFR) before and $5 \mathrm{~min}, 30 \mathrm{~min}, 1 \mathrm{~h}, 2 \mathrm{~h}, 4 \mathrm{~h}, 6 \mathrm{~h}$, and $24 \mathrm{~h}$ after the provocation. Histamine challenge was performed according to Cockroft before, and $24 \mathrm{~h}$ after SIT [11] .

Induced sputum and nasal lavage fluid

Cellular and biochemical profiles of nasal washings were determined for all patients. All the procedures were similar as in the 'nasal pool' method [12,13]. Nasal washings were collected immediately before the provocation, and $4 \mathrm{~h}$ and $24 \mathrm{~h}$ afterwards.

Cellular and biochemical profiles of induced sputum (ISP) were analysed in 24 patients. ISP testing was performed before and $22 \mathrm{~h}$ after SIT. The whole process of collecting ISP has been described elsewhere $[13,14]$.

Exhaled nitric oxide measurements

Nitric oxide was measured with a chemiluminescence analyser (NIOX, Aerocrine, Sweden) adapted for online recording of NO concentrations. This chemiluminescence analysis is based on the reaction of NO with ozone, which 
allows measurements down to approximately 1 part per billion (ppb). Measurements of eNO were performed as in the recommendations of the American Thoracic Society (ATS) Documents [15]. Measurements of eNO were made during three exhalation manoeuvres and mean values were calculated. Values $<20 \mathrm{ppb}$ were regarded as normal.

The measurements were carried out in the morning before the challenge tests and $5 \mathrm{~min}, 1 \mathrm{~h}, 2 \mathrm{~h}, 3 \mathrm{~h}, 4 \mathrm{~h}, 5 \mathrm{~h}$ and $24 \mathrm{~h}$ after SIT. Each measurement was made before the spirometry. Patients were asked not to smoke or have a heavy meal just before NO measurements.

\section{Diagnostic criteria}

Hypersensitivity to any allergen has been defined as at least one positive result of SPT and/or positive specific serum IgE assay [16]. Diagnosis of occupational allergic rhinitis $[17,18]$ was based on work-related symptoms and positive nasal response to the provocation test i.e. a total score of more than 3 [17] and a significant increase in the proportion of eosinophils [17,18]. We regarded the nasal challenge test positive when the increase in eosinophils proportion persisted for up to $24 \mathrm{~h}$ after the provocation and when a two-fold increase in these parameters was observed $[14,19]$.

OA [15] was diagnosed in subjects reporting work-related chest symptoms, for whom SIT was found to induce an early or dual asthmatic reaction (at least a 20\% decrease in $\mathrm{FEV}_{1}$ ) or a three-fold increase in non-specific bronchial hyperactivity $\left(\mathrm{PC}_{20}\right)$.

\section{Statistical analysis}

The eNO levels were compared with basal values by the paired t-test. The data were expressed as the mean $\pm \mathrm{SD}$. Correlations were assessed by Pearson's rank method. The differences were regarded as significant at $\mathrm{p}<0.05$.

\section{RESULTS}

The characteristics of the study group are shown in Table 1 . The mean age of the subjects was $43.9 \pm 9.80$ years. The group comprised 17 (40.5\%) farmers, 15 (35.7\%) bakers, and $10(23.8 \%)$ HCWs. From the analysis of positive
Table 1. Characteristics of study population

\begin{tabular}{lc}
\hline \multicolumn{1}{c}{ Study parameter } & Patients $(\mathrm{n}=42)$ \\
\hline Age (Mean $\pm \mathrm{SD})$ (years) & $43.9 \pm 9.80$ \\
Gender & $24(57.1 \%)$ \\
Male & $18(42.9 \%)$ \\
Female & $15.8 \pm 9.75$ \\
Employment duration (Mean $\pm \mathrm{SD})$ (years) & $13.07 \pm 10.16$ \\
Bakers $(\mathrm{N}=15)$ & $16.47 \pm 10.09$ \\
Farmers $(\mathrm{N}=17)$ & $18.6 \pm 8.4$ \\
Health care workers $(\mathrm{N}=10)$ & $7.27 \pm 6.40$ \\
Mean latency period of reported symptoms & \\
(Mean \pm SD) (years) & $4.46 \pm 2.58$ \\
Bakers & $10.35 \pm 7.36$ \\
Farmers & $6.25 \pm 6.9$ \\
Health care workers & $10(23.8 \%)$ \\
Family history of atopic diseases & \\
Smoking status & $5(11.9 \%)$ \\
Active smokers & $14(33.3 \%)$ \\
Ex-smokers & $23(54.8 \%)$ \\
Never-smokers & \\
\hline
\end{tabular}

family history of allergic diseases, ten subjects (23.8\%) were assumed to be atopic. Five subjects $(11.9 \%)$ were active smokers and 14 (54.8\%) ex-smokers.

The mean total IgE level was $140.8 \pm 177.5 \mathrm{kU} / \mathrm{l}$. Positive SPT to at least one common allergen was found in $28(66.7 \%)$ subjects out of the 42 taking part in the study and to occupational allergen in $18(42.9 \%)$ participants. The incidence of skin reactivity to occupational allergens was similar among bakers and farmers. The most frequent allergens of skin reactivity among bakers was corn flour, while among farmers were storage mites. Positive SPTs with latex allergens were recorded in 1 subject.

Specific IgE to occupational allergens was found in 13 (30.9\%) subjects (Table 2).

Serum sensitisation to occupational allergens developed most frequently among bakers.

SIT induced very severe symptoms of rhinitis in 17 out of 19 subjects with diagnosed occupational airway allergy (SOAA) (asthma and/or rhinitis) (score: $1.17 \pm 0.88$ before and $4.64 \pm 0.68$ immediately after; $6.78 \pm 0.82$ at $4 \mathrm{~h}$ and $5.0 \pm 0.75$ at $24 \mathrm{~h}$ after SIT, respectively $\mathrm{p}<0.05 \mathrm{vs}$. baseline value).

The reactions to flours in subjects with atopic asthma (SAA) and in subjects without airway allergy (SWAA) 
Table 2. Laboratory findings

\begin{tabular}{lc}
\hline \multicolumn{1}{c}{ Study parameter } & $\begin{array}{c}\text { Patients } \\
\mathrm{n}(\%)\end{array}$ \\
\hline All subjects participating in the study & $42(100 \%)$ \\
Total IgE (mean \pm SD) kU/l & $140.8 \pm 177.5$ \\
Positive SPT with at least one common & \\
allergen & $28(66.7 \%)$ \\
Bakers & $12(28.6 \%)$ \\
Farmers & $11(26.2 \%)$ \\
Health care workers & $4(9.5 \%)$ \\
Serum sIgE with occupational allergens & $13(30.9 \%)$ \\
Bakers & $9(21.4 \%)$ \\
Farmers & $3(7.1 \%)$ \\
Health care workers & $1(2.4 \%)$ \\
Positive SPT with at least one occupational & \\
allergen & $18(42.9 \%)$ \\
Bakers [N = 15 (100\%)] & $13(30.9 \%)$ \\
Wheat flour & $3(20.0 \%)$ \\
Corn flour & $4(26.7 \%)$ \\
Oatmeal flour & $2(13.3 \%)$ \\
Barley flour & $3(20.0 \%)$ \\
Threshings & $3(20.0 \%)$ \\
$\alpha$-amylase & 0 \\
Farmers [N = 17 (100\%)] & $14(33.3 \%)$ \\
Animal allergens & $3(17.6 \%)$ \\
Hay and straw dust & $1(5.9 \%)$ \\
Cereals & $3(17.6 \%)$ \\
Storage mites & $4(23.5 \%)$ \\
Health care workers [N = 10 $(100 \%)]$ & $1(2.4 \%)$ \\
Latex allergens & $1(10.0 \%)$ \\
\hline
\end{tabular}

were slight, so the differences did not reach the level of statistical significance.

Occupational airway allergy (OAA) was diagnosed in 19 subjects, including 17 subjects with asthma and occupational allergic rhinitis and 2 cases with $\mathrm{OA}$ alone. Atopic

Table 3. Clinical features

\begin{tabular}{lr}
\hline \multicolumn{1}{c}{ Diagnosis } & $\mathrm{n}(\%)$ \\
\hline Occupational asthma + occupational rhinitis & $17(40.5 \%)$ \\
Asthmatic dual response & $10(23.8 \%)$ \\
Asthmatic early response & $7(16.7 \%)$ \\
$\mathrm{PC}_{20}$ his $(\mathrm{mg} / \mathrm{ml})$ before SIT & $6.4 \pm 1.8$ \\
$\mathrm{PC}_{20}$ his, 24 h $(\mathrm{mg} / \mathrm{ml})$ & $2.1 \pm 0.9 *$ \\
Occupational asthma alone & $2(4.7 \%)$ \\
Atopic non-occupational asthma and rhinitis & $6(14.3 \%)$ \\
Without airway allergy & $17(40.5 \%)$ \\
Total & $42(100.0 \%)$ \\
\hline
\end{tabular}

$* \mathrm{p}<0.05$ vs. baseline value. bronchial asthma was diagnosed in 6 patients and in 17 cases we did not diagnose any allergic airway disease (Table 3).

Of the 42 active specific inhalation tests (SITs), 19 were positive (asthmatic dual or early response and/or increased bronchial responsiveness to histamine) and 23 were negative (Table 3). Positive results of SIT were found in 12 bakers, 5 farmers, and 2 HCWs.

Statistically significant difference in $\mathrm{PC}_{20}$ was found in SOAA after SIT (Table 3).

The provocation with allergen did not induce significant changes in $\mathrm{FEV}_{1}$ and $\mathrm{PC}_{20}$ in any subject from the control groups.

The SIT caused a significant increase in the proportion of eosinophils either in NLF or ISP of 19 individuals with diagnosed OAA, $\mathrm{p}<0.05$ (Table 4).

A slight change in the proportion of eosinophils was noted either in NLF or ISP of subjects with atopic non-occupational asthma, but the differences did not reach the level of statistical significance, $p>0.05$ (Table 4).

Table 4. Percentage of eosinophils in nasal lavage fluid and induced sputum in subjects with diagnosed occupational airway allergy and the controls before and after SIT

\begin{tabular}{lccc}
\hline $\begin{array}{c}\% \text { of } \\
\text { eosinophils }\end{array}$ & Before SIT & $4 \mathrm{~h}$ after & $\begin{array}{c}24 \mathrm{~h} \text { after }-\mathrm{NLF} \\
22 \mathrm{~h}-\mathrm{ISP}\end{array}$ \\
\hline $\begin{array}{l}\text { Subjects with } \\
\text { diagnosed }\end{array}$ & & & \\
OAA & & & \\
NLF & $3.9 \pm 1.7$ & $10.4 \pm 4.3^{*}$ & $13.4 \pm 4.9^{*}$ \\
ISP & $5.2 \pm 3.8$ & & $17.2 \pm 8.0^{*}$ \\
Atopic non- & & & \\
occupational & & & \\
asthma and & & & \\
rhinitis & & & $1.8 \pm 0.7$ \\
NLF & $1.3 \pm 0.09$ & $1.8 \pm 1.0$ & \\
ISP & $12.0 \pm 5.6$ & & \\
Subjects & & & \\
without & & & $1.7 \pm 1.3$ \\
airway allergy & & & $4.6 \pm 3.8$ \\
NLF & $1.7 \pm 1.4$ & $1.8 \pm 1.1$ & \\
ISP & $5.0 \pm 3.5$ & & \\
\hline
\end{tabular}

$* p<0.05$ vs. baseline value.

NLF - nasal lavage fluid, ISP - induced sputum, OAA - occupational airway allergy. 


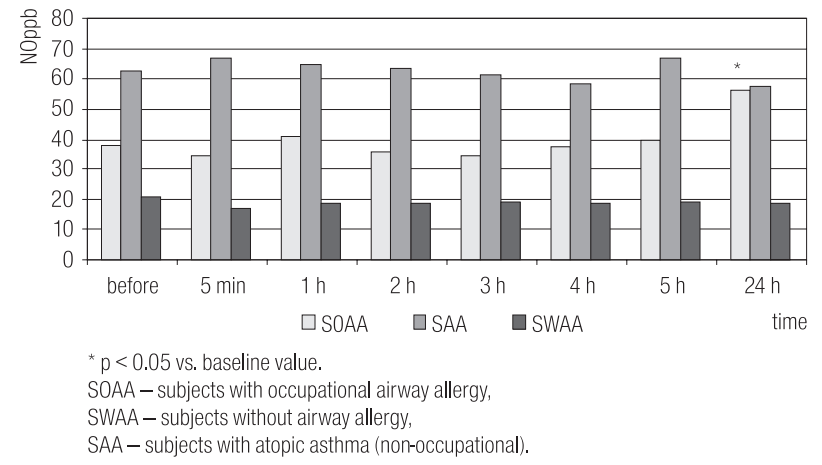

Fig 1. eNO levels after specific challenge test.

No significant changes in the proportion of eosinophils were observed either in NLF or ISP of SWAA after SIT, p > 0.05 (Table 4).

Moreover, those 19 subjects with OAA also showed a significant increase in eNO levels only $24 \mathrm{~h}$ after SIT compared to the pre-SIT measurements $(\mathrm{p}<0.05)$ (Figure 1).

No significant changes in eNO levels were observed at any time point after SIT either in subjects with atopic nonoccupational asthma or in subjects without any airway allergy.

The findings of the study revealed a significant correlation between eNO level $24 \mathrm{~h}$ after SIT and the percentage of eosinophils in NLF of 19 subjects with OAA before, and $4 \mathrm{~h}$ and $24 \mathrm{~h}$ after SIT (Pearson $\mathrm{r}=0.50, \mathrm{r}=0.54$, and $r=0.47$, respectively; $p<0.05)$ and also in ISP of the same group before and $24 \mathrm{~h}$ after SIT (Pearson $\mathrm{r}=0.17$, and $r=0.24$, respectively; $p<0.05)$.

\section{DISCUSSION}

SIT is the most appropriate way to diagnose OA. Asthmatic reaction is followed by the changes in the functional parameters, such as $\mathrm{FEV}_{1}$ or peak expiratory flow (PEF), as well as changes in airway responsiveness to histamine and morphological and biochemical changes in ISP and NLF. There are reports indicating that exhaled nitric oxide measurements can give additional information useful for the interpretation of occupational challenge tests [18]. Significant increase in eNO after SIT indicates allergeninduced inflammatory reaction [20].
In our study, we found a significant increase in eNO concentration $24 \mathrm{~h}$ after SIT in 19 patients with diagnosed $\mathrm{OA}$. These results are consistent with earlier reports showing elevated eNO levels after allergen challenges at the time of the late response [21-23]. It is unlikely that our NO measurements could be partly affected by NO derived from nasal cavities by diffusion. According to the ATS recommendation, the mouth pressure obtained during the study was $5 \mathrm{~cm} \mathrm{H}_{2} 0$ [15]. It has been proved that a low positive mouth pressure - about $4 \mathrm{~cm} \mathrm{H}_{2} 0$ during exhalation is sufficient to close up the soft palate and separate the nasal from the oral cavity, thereby eliminating the contamination of the sample with nasal air [24]. Reports are available describing nasal $\mathrm{NO}$ increase after nasal allergen challenge [25] but we could not find any article dealing with the relationship between changes in nasal $\mathrm{NO}$ and bronchial allergen challenge.

Several reports are accessible considering eNO measurements in the diagnostics of occupational allergy. Baur et al. investigated latex allergen-induced eNO changes in different groups of HCWs [26]. Only latex-sensitised employees showed a significant eNO increase $22 \mathrm{~h}$ after the challenge. These findings correspond with those of an earlier study by the same author, where an active challenge with isocyanate caused the highest increase in eNO level also after $22 \mathrm{~h}$ [27].

There was also an increase in the percentage of eosinophils without any increase in eNO level in subjects with atopic non-occupational asthma. The explanation of that fact is not simple, probably the expression of iNOS could be reached earlier in subjects sensitised to the occupational allergens after the specific challenge tests than in nonsensitised individuals. We think that further studies should be performed to elucidate this point.

Both ISP and NLF examinations are reliable research tools for measuring allergen-induced airway inflammation in asthma and allergic rhinitis. They are generally approved for use in the diagnostics of OA $[19,28]$.

In this study, we found a significant increase in the proportion of eosinophils in ISP from OA patients at $24 \mathrm{~h}$ after SIT, compared to baseline values. We also observed a significant influx of eosinophils in NLF from subjects with 
diagnosed OA at 4 and $24 \mathrm{~h}$ after SIT. The majority of subjects with diagnosed occupational asthma had also allergic rhinitis, so our findings support earlier observations that nasal inflammation may reflect bronchial allergic inflammatory reaction [29].

The present study revealed a significant correlation between the percentage of eosinophils in ISP and NLF and the level of exhaled NO after SIT in 19 subjects with diagnosed OAA. Our observations confirm the results obtained by other authors. Jatakanon et al. have demonstrated a relationship between exhaled NO and the fraction of eosinophils in ISP. They measured sputum eosinophils and exhaled NO in a group of stable asthmatics maintained on $\beta_{2}$-agonists alone, and found a significant correlation between the two parameters [8]. Canadian authors have found a significant relationship between exhaled NO and sputum eosinophils in subjects with Western redcedar-induced OA who continued to be exposed and in those who failed to recover after removal from the exposure [30]. Our findings confirm that further studies should be performed to compare allergen-induced changes in eNO level as an indirect marker for changes in bronchial and/or nasal inflammation.

We conclude that exhaled nitric oxide measurements may be used as a complementary tool for the interpretation of occupational challenge tests, but other data are necessary for the determination of its sensitivity.

\section{REFERENCES:}

1. Bhagat K, Vallance P. Nitric oxide 9 years on. J R Soc Med 1996;89(12):667-73.

2. Hamid Q, Springall DR, Riveros-Moreno V, Chanez P, Howarth P, Redington A, et al. Induction of nitric oxide synthase in asthma. Lancet 1993;342:1510-3.

3. Silkoff PE, Robbins RA, Gaston B, Landberg JO, Townley RG. Endogenous nitric oxide in allergic airway disease. J Allergy Clin Immunol 2000;105(3):438-48.

4. Lane C, Knight D, Burgess S, Franklin P, Horak F, Legg J, et al. Epithelial inducible nitric oxide synthase activity is the major determinant of nitric oxide concentration in exhaled breath. Thorax 2004;59:757-60.
5. Alving K, Weitzberg E, Lundberg JM. Increased amount of nitric oxide in exhaled air of asthmatics. Eur Respir J 1993;6:1368-70.

6. Senna G, Passalacqua G, Schiappoli M, Lombardi C, Wilcock L. Correlation among FEV ${ }_{1}$ nitric oxide and asthma control test in newly diagnosed asthma. Allergy 2007;62(92):207-8.

7. Smith AD, Cowan JO, Filsell S, McLachlan C Smith AD, Cowan JO, et al. Diagnosing asthma. Comparisons between exhaled nitric oxide measurements and conventional tests. Am J Respir Crit Care Med 2004;169;473-9.

8. Jatakanon A, Lim S, Kharitonov SA, Chung KF, Barnes PJ. Correlation between exhaled nitric oxide, sputum eosinophils, and methacholine responsiveness in patients with mild asthma. Thorax 1998;53:91-5.

9. Silvestri M, Spallarossa D, Frangova Yourukova V, Battistini E, Fregonese B, Rossi GA. Orally exhaled nitric oxide levels are related to the degree of blood eosinophilia in atopic children with mild-intermittent asthma. Eur Respir J 1999;13:321-6.

10. Dreborg S, Frew AJ, editors. Allergen standardization and skin tests. Allergy 1993;48(Suppl 14):49-82.

11. Cockroft DW, Killian DN, Mellon JJA, Hargreave FE. Bronchial reactivity to inhaled histamine: a method and clinical survey. Clin Allergy 1977;7:235-43.

12. Greiff L, Pipkorn U, Alkner U, Persson CGA. The 'nasal pool' device applies controlled concentrations of solutes on human nasal airway mucosa and samples its surface exudations/ secretions. Clin Exp Allergy 1990;20:253-9.

13. Krakowiak A, Krawczyk-Adamus P, Dudek W, Walusiak J, Pałczyński C. Changes in cellular and biochemical profiles of induced sputum after allergen-induced asthmatic response: method for studying occupational allergic airway inflammation. Int J Occup Med Environ Health 2005;18(1):27-33.

14. Górski P, Krakowiak A, Pazdrak K, Palczynski C, Ruta U, Walusiak J. Nasal challenge test in the diagnosis of allergic respiratory diseases in subjects occupationally exposed to a high molecular allergen (flour). Occup Med 1998; 48(2):91-7.

15. American Thoracic Society. ATS/ERS recommendations for standardized procedures for the online and offline measurement of exhaled lower respiratory nitric oxide and nasal nitric oxide, 2005. Am J Respir Crit Care Med 2005;171:912-30. 
16. Johanson SGO, Hourihane JO’B, Bousquet J, BruijnzeelKoomen C, Dreborg S, Haahtela T, et al. a revised nomenclature for allergy: An EAACI position statement from the EAACI nomenclature task force. Allergy 2001;56(9): 813-24.

17. Wihl JA. Methodological aspects of nasal allergen challenges based on tree-pollen immunotherapy study. Allergy 1986;41(5):357-64.

18. Pałczyński C, Walusiak J, Ruta U, Górski P. Occupational asthma and rhinitis due to glutaraldehyde: changes in nasal lavage fluid after specific inhalatory challenge test. Allergy 2001;56(12): 1186-91.

19. Pałczyński C, Walusiak J, Ruta U, Górski P. Nasal provocation test in the diagnosis of natural rubber latex allergy. Allergy 2000;55(1):34-41.

20. Piipari R, Piirilä P, Keskinen H, Tuppurainen M, Sovijärvi A, Nordman H. Exhaled nitric oxide in measurements in specific challenge tests to assess occupational asthma. Eur Respir J 2002;20:1532-7.

21. Kharitonov SA, O'Connor BJ, Evans DJ, Barnes PJ. Allergen-induced late asthmatic reactions are associated with elevation of exhaled nitric oxide. Am J Respir Crit Care Med 1995;151(6):1894-9.

22. Paredi P, Leckie MJ, Horvath I, Allegra L, Kharitonov SA, Barnes PJ. Changes in exhaled carbon monoxide and nitric oxide levels following allergen challenge in patients with asthma. Eur Respir J 1999;13:48-52.

23. Thomassen MJ, Raychaudhuri B, Dweik RA, Farver C, Buhrow L, Malur A, et al. Nitric oxide regulation of asth- matic airway inflammation with segmental allergen challenge. J Allergy Clin Immunol 1999;104(6):1174-82.

24. Silkoff PE, McClean PA, Slutsky AS, Furlott HG, Hoffstein E, Wakita S, et al. Marked flow-dependence of exhaled nitric oxide using a new technique to exclude nasal nitric oxide. Am J Respir Crit Care Med 1997;155:260-7.

25. Kirsten AM, Jörres RA, Kirsten D, Magnussen H. Effect of a nasal challenge with endotoxin-containing swine confinement dust on nasal nitric oxide production. Eur J Med Res 1997;2(8):335-9.

26. Baur X, Barbinova L. Latex allergen exposure increases exhaled nitric oxide in symptomatic healthcare workers. Eur Respir J 2005;25:309-16.

27. Barbinova L, Baur X. Increase in exhaled nitric oxide (eNO) afterwork-related isocyanate exposure.Int Arch OccupEnviron Health 2006;79(5):387-95.

28. Lemiere C, Pizzichini MM, Balkissoon R, Clelland L, Efthimiadis A, O'Shaughnessy D, et al. Diagnosing occupational asthma: use of induced sputum. Eur Respir J 1999;13: 482-88.

29. Bousquet J, van Cauwemberg P, Khaltaev N, ARIA Workshop Group, World Health Organization. Allergic rhinitis and its impact on asthma. J Allergy Clin Immunol 2001;108 (Suppl 5):S147-334.

30. Chan-Yeung M, Obata H, Dittrick M, Chan H, Abboud R. Airway inflammation, exhaled nitric oxide, and severity of asthma in patients with Western red cedar asthma. Am J Respir Crit Care Med 1999;159(5):1434-38. 